\title{
Transcultural journeys: The disembedding and re- embedding of Sepik art
}

Un voyage transcultural : désimplantation et réimplantation dans l'art du Sepik

\section{Brigitta Hauser-Schäublin}

\section{(2) OpenEdition \\ 1 Journals}

Electronic version

URL: http://journals.openedition.org/jso/8679

DOI: $10.4000 /$ jso.8679

ISSN: $1760-7256$

\section{Publisher}

Société des océanistes

\section{Printed version}

Date of publication: 15 July 2018

Number of pages: 165-177

ISBN: 978-2-85430-135-9

ISSN: 0300-953x

\section{Electronic reference}

Brigitta Hauser-Schäublin, «Transcultural journeys: The disembedding and re-embedding of Sepik art », Journal de la Société des Océanistes [Online], 146 | 2018, Online since 15 July 2020, connection on 24 July 2020. URL : http://journals.openedition.org/jso/8679; DOI : https://doi.org/10.4000/jso.8679

(c) Tous droits réservés 


\title{
Transcultural journeys: the disembedding and re-embedding of Sepik art
}

by

\author{
Brigitta HAUSER-SCHÄUBLIN*
}

\begin{abstract}
Artefacts have always been part of inter-and transcultural journeys in the Sepik. People and artefacts had been continuously moving throughout the area in pre-colonial New Guinea due to migrations, exchange and plundering. However, the scope and the quality of these journeys changed fundamentally when the process of disembedding of artefacts started with the collecting activities of explorers in the colonial area. Against the backdrop of the transmaritime journeys of textiles from India to the Southeast Asian archipelago in pre-colonial times, this article highlights the special features of the Sepik case. The dislocation of predominantly old and "authentic" Sepik artefacts to places in the western world resulted in their transformation and re-embedding in new settings. A proliferation of transformations and reinterpretations of Sepik art began with the transcultural journeys of artefacts to multiple destinations since the intensification of globalisation, resulting in stories about the artefacts with conflicting interpretations and consequences.
\end{abstract}

KEYwords: Transcultural journeys, patola, colonial collecting, disembedding, transformations

\section{Transcultural journeys of artefacts}

Diffusionism - a result of the study of museum collections - has already investigated the movement of things through time and space by identifying similarities in form and function of objects in different places and cultures. Only globalisation studies raised similar questions by taking concrete evidence of such movements as the starting point and focusing more on the actors involved, the conditions and

\section{RÉSUMÉ}

Dans le Sepik, les artefacts ont toujours voyagé entre cultures. À l'époque précoloniale, suite aux migrations, aux échanges et aux pillages, les populations et les objets ont toujours migré entre les régions. Cependant le périmètre et la qualité de ces voyages transculturels changèrent considérablement quand le processus de délocalisation des objets commença avec les collectes des explorateurs à l'époque coloniale. En s'appuyant sur l'exemple de l'échange par voies maritimes des textiles entre l'Inde et l'archipel de l'Asie du Sud-Est à l'époque précoloniale, cet article éclaire les formes particulières de l'échange dans le Sepik. La dispersion des objets anciens et "authentiques" du Sepik dans différents lieux du monde occidental a eu pour effet de les transformer en les intégrant dans un nouvel environnement. La prolifération des transformations et des réinterprétations de l'art du Sepik commença lors des voyages d'objets dans des directions diverses, nationales et internationales. Il en naquit des histoires d'objets avec des interprétations contradictoires et leurs conséquences.

MoTS-CLÉs : voyages transculturels, patola, collectes coloniales, délocalisation, transformations

the way in which "things" (as well as ideas and people) moved transculturally and became localised in new cultural contexts (Appadurai, 1996). In this article, I apply a comparative approach by delineating first the transcultural journey of patola textiles and the transformations these textiles underwent on their way from India to different cultures and places in insular Southeast Asia (including West Papua). These transformations started in pre-colonial times and outside of the European spheres of influence. 
By contrast, Sepik artefacts entered long-distance trade channels only with the beginning of colonialism. It was under these conditions that the artefacts were provided with new stories or appeared in new material guises when they were fed into colonial, globalised channels and reached new destinations, be it Western museums or anti-traditionalist circles within the nation of Papua New Guinea (PNG).

As I am going to show, there exist a number of crucial differences between the colonial and the pre-colonial trafficking of cultural goods, especially regarding the evaluation of these things. New Guinea was not an isolated island pre-colonially but had already been part of long-distance intermaritime networks of trade and exchange. The major goods were plumes of paradise (Swadling, 1996), forest products, slaves, beads and textiles, linking New Guinea not only to islands of the Indonesian archipelago but also, directly or indirectly, to India and beyond (Timmer, 2011). I will use the well-documented trading of textiles - patola textiles from India which also reached west New Guinea (Papua) - as a backdrop against which the particularity of the capitalistic acquisition and trafficking of cultural goods from New Guinea, especially the Sepik region, becomes more obvious. It is this comparison of two different forms of trading, the pre-colonial and the colonial, that provides new insights into the particularity of the way artefacts have been appropriated, reinterpreted and repurposed since colonial time.

I am going to delineate three forms of transcultural journeys of Sepik artefacts and the way they have been evaluated and interpreted by those who received or used them in their own contexts. In a first step, I will highlight the colonial acquisition of ethnographic items by colonial functionaries, traders and collectors according to the dominant system of value at the time. A second form of transcultural journeys, also originating from the Sepik, consists of the multidirectional flow of forms and motifs and stories told about them, on the one hand, and the adaption of new materials to old forms, on the other. A third form of transcultural journeys of Sepik artefacts is more recent and concerns the free floating of images and meanings, often detached from each other, within the nation state of PNG. In all these transcultural journeys - mostly long-distance travels across a number of cultures - I will focus on the criteria of evaluation and the (re-)interpretation of these cultural goods (photo 1).

\section{"Sepikness" as a result of interactions}

The title of the 2015 colloquium on the Sepik "The materiality of Sepik societies: new visions, old problems" raises the questions of what Sepik societies and their "materiality" are. Reche (2015:
465-473) distinguished "cultural regions" within north-eastern New Guinea and delineated "style provinces" based on similar and different features of material artistic expressions within the Sepik basin. Margaret Mead called the Middle Sepik a "culture area" (1938: 157), that is,

"an area within which the same basic ideas recur repeatedly and throughout which traffic in material and non-material items of culture is common."

Among the characteristics she identified were linguistic diversity and

"a self-conscious diffusion of non-material traits, coupled with a premium upon new importations, resulting in continual loss and reimportation of similar traits." (Mead, 1938: 157)

Anthony Forge attempted a similar approach that took culture not societies as a starting point. As he pointed out, the

"tendency toward particularism has always been counterpointed by the existence of certain remarkable regional continuities in the style of its arts." (Mijas, 1986; Forge, 2017: 175)

Commenting on these considerations, Lutkehaus and Roscoe coined the term "Sepikness", by which they understood the paradox already outlined by Forge: similarities and continuity and, at the same time, cultural diversity in the Sepik region, which is, as Margaret Mead had already emphasised, a cultural area (Lutkehaus and Roscoe, 1987). This "Sepikness" is indeed reflected in Sepik art. However: What is "the Sepik" or what are "Sepik societies"?

The anthropological perspective on Sepik cultures has changed gradually since the late 1980s: It moved from the assumption of seemingly more or less fixed ethnolinguistic units, such as the "Iatmul", "Sawos", "Abelam" and "Boiken", to consider the Sepik basin as a permeable area with rather small groups of people moving continuously through it in pre-colonial times (Roscoe, 1989; Claas, 2007). This shift in perspective showed that closed ethnic units - apparently the result of single-village based research and the anthropological notion of "tribes" - never existed. They turned out to be powerful Western inventions (Claas, 2009) that, over time, have become part of local people's discourse (Silverman, 1993: 60). As Claas' analysis showed, small-scale migrations throughout the middle Sepik took place in different directions (Claas 2007, 2009; see also, for example, Wassmann, 1991; Newton, 2015: 99; McDowell, 2015). Settlements often split up, mostly after disputes, raids or natural disasters, and one party of people (either the surviving or the defeated) moved to another place. 


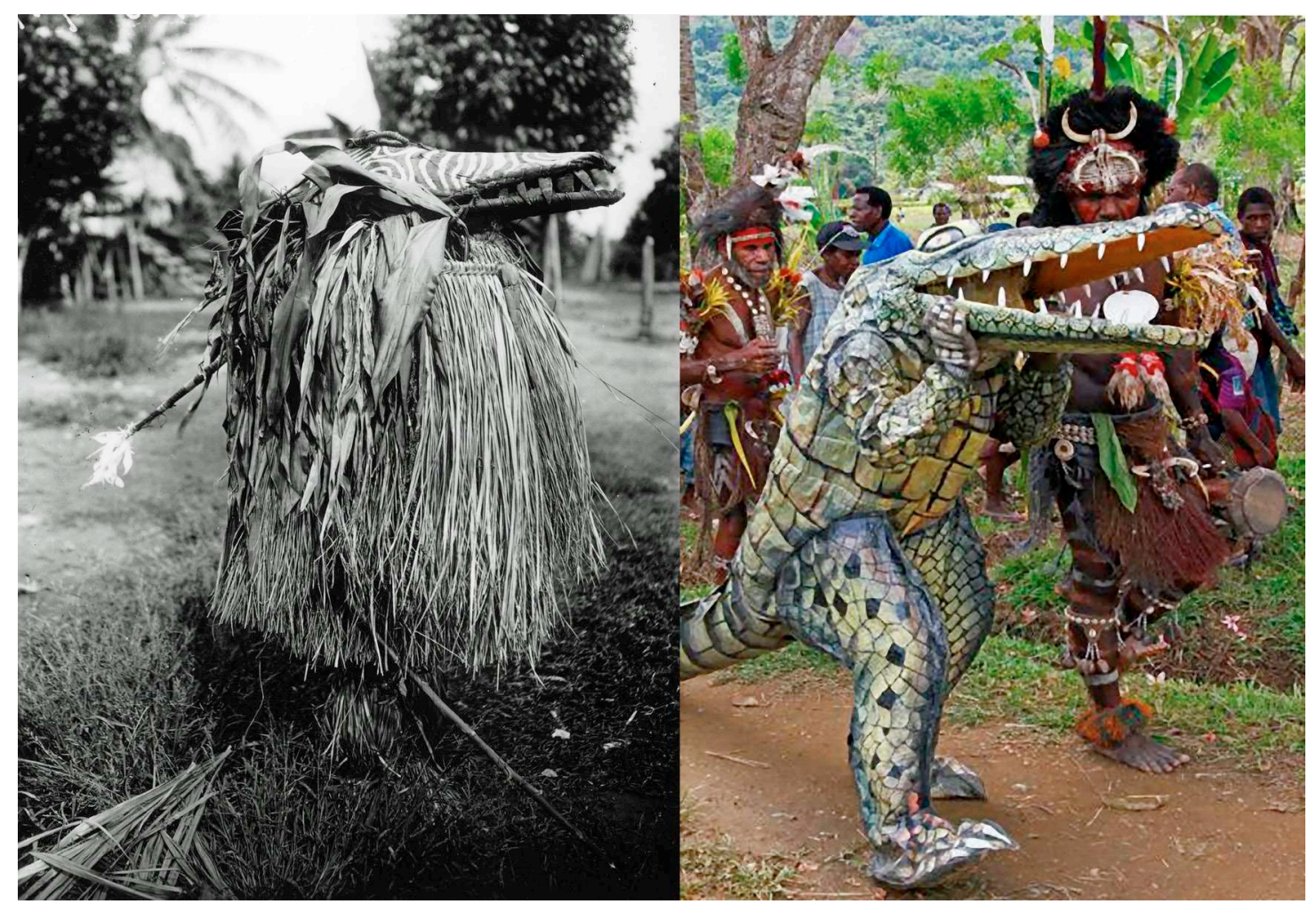

Рното 1. - Old stories and new material expressions: crocodile mask collected in "Kandanam" by the Sepik expedition in 1912-13 and crocodile performance during the Crocodile Festival in Ambunti, 2014 (Courtesy of Papua New Guinea Tourism Promotion Authority)

The migrants sometimes displaced other people in areas already inhabited (such as the Arapesh), merged with people in other locations or set up their own settlement (Hauser-Schäublin, 2016: 1-36). As Aikhenvald pointed out, due to migration, people also changed their livelihood systems and even their language (Aikhenvald, 2008: 23-24). Moreover, recent linguistic analysis suggests that the languages of the Iatmul, Sawos, Boiken and Abelam need to be classified as dialects of the same language, the Ndu language (Jendraschek, 2012: 7). Foley even speaks of "Creolization" of the Abelam, Boiken and Iatmul languages as a result of having assimilated "less viable languages". ${ }^{1}$ According to Foley's hypothesis, this may have happened as a consequence of long-distance communication due to trade (and migration) (Foley, 2017: 200-201). Although culture and language do not need to be congruent (that is, people may share the same culture though speaking different languages, and vice versa), these findings - dialects instead of separate languages and "creolization" - support the results of the studies about the migration dynamics in the area.

In brief: Relationships and forms of belonging between different settlements, or rather their inhabitants, were shaped consonant with their history of ongoing migration, the performance of alliances and feuds, marriages, exchange of staple and other goods, ritual partnership and a regional ritual division of labour. These intercultural interactions (those between neighbouring groups), however, were not limited to the members of the Ndu language family but went far beyond and included villages and groups on the lower Sepik whose language cannot be related to the $\mathrm{Ndu}$ family (Aikhenvald, 2008: 22). ${ }^{2}$ These relationships create maps that display anything but closed ethnic units, on the contrary. Moreover, no social "centres" existed that could establish structures and relations of dominance and subjection, as Kocher Schmid suggested (2015: 69). ${ }^{3}$

1. Foley, who still uses the concept of "Ndu family", relates "a minimum of [...] seven languages" to it (Foley, 2017: 242).

2. Roesicke had already mentioned in his diary that he met three canoes with 13 men and 2 women in them on the "SüdFluss" (Krosmeri River). The canoes were loaded with betel nuts. The people said they came from "Kaurima" and were on their way to Mindimbit. However, Roesicke met them next a few days later in Kararau (March 16 to 18, 1913). A day later, a group of eleven men from "Kabliman" (Kapriman) landed in Kararau; they, too, came for barter (Schindlbeck, 2015: 261-26).

3. Gewertz (1983), in her attempt to outline a cultural history of the Middle Sepik, attributed a dominant role to the Iatmul, especially over the non-river, sago-producing villages. At that time, only limited data concerning oral migration histories were available, most of them published in German. Together with the opinion of early travellers and art collectors, this version of history became solidified and transmitted without taking notice of recent research. 
Thus, these continuous micro migrations and the sometimes overlapping networks of barter, ritual exchange and feuds/alliances between villages produced a region of transition with a singular density of interactions. Thus, speaking of "the Iatmul", "the Boiken" or "the Abelam" is no more than a heuristic device used by scholars that does not mirror the reality. Concerning art, there were also no centres and peripheries, as some scholars suggested by their attempt to establish style areas (Speiser, 1937; Bühler, 1960; for a critique, see Claas, 2009). ${ }^{4}$ The differences between "Boiken", "Abelam" or "Iatmul" art can only be made out if the points of reference are parts of regions that are quite distant from each other, such as northern Abelam villages and the central Iatmul villages. The picture is different if one considers and compares "fringe" villages in the grassland, either in Wosera or Yangoru-Saussia. If these villages and their artistic expressions were taken as a starting point, the perspective on what is considered Abelam or Iatmul art would be different; they would appear as exaggerations of a basically shared set of characteristics.

Moreover, not only people had been moving through the area between the Torricelli and Alexander Mountains, the Sepik River and the southern tributaries, but also artefacts due to exchange, ritual prestation, plundering or migration. By such transfers, the artefacts often changed the way in which they were used and, correspondingly, their meaning (Peltier and Schindlbeck, 2015: 15). Moreover, the borrowing by translating one expression of art from one area within the Sepik to the next also seems to have happened on a regular basis. As I have recently investigated in one special case (mai masks), it was not a copying that took place but a transposition and culture-specific re-creation, from the "model" of a decorated ritual dancer to a mask with costume (Hauser-Schäublin, 2017). Such forms of transfers, together with multilayered movements of people in the region, contributed to the development of some shared features of Sepik art ("Sepikness") and, at the same time, favoured specific local expressions for several reasons: people live in different ecological zones, people's endeavour to distinguish themselves from others, and artists' creativity and ingenuity.

This situation changed when the first Europeans entered the scene and colonisation started. The prohibition of warfare influenced the intervillage relationships and, consequently, also men's ritual life - and art. The pacification and colonial mapping of the Sepik with the identification of village sites and territories put an end to migrations of entire groups (Gewertz, 1983: 123; Hauser-Schäublin, 2016:
3-14; Schindlbeck, 2017). Moreover, the first Europeans were interested in acquiring artefacts. This was the beginning of the establishment of Sepik collections which are now spread over the whole globe. It was at this point in history when the circulation of artefacts, the ideas and interpretation of their use and meaning crossed the Sepik basin and entered new channels. The artefacts became "disembedded" from their Sepik context and re-embedded in new contexts. Thus, the transcultural, long-distance journey of Sepik artefacts started and led them to places their producers had never heard of. From these remote places (seen from the perspective of Sepik societies), artefacts, pictures, ideas and stories about them circulated around the whole world - and reached New Guinea again in the form of repercussions. The artefacts displayed an agency, in Gell's sense (1998), that attracted different circles of peoples worldwide who "saw" different things in them and stimulated these people to different actions.

Prior to exploring Sepik transcultural journeys in more detail, I will first present one of the best documented examples of transcultural journeys of artefacts - textiles known as patola from Gujarat to insular Southeast Asia (Bühler and Fischer, 1979) - that had already begun hundreds of years before the advent of Europeans in Asia. ${ }^{5}$ I will start with a brief delineation of this pre-colonial trade and the transformation these textiles underwent on their way from India to various destinations in the Southeast Asian archipelago. I will use this summary as a backdrop to make visible distinct features of the transcultural journeys of Sepik artefacts.

\section{The exemplar of transcultural journeys in pre- colonial times}

The genuine double-ikat textiles (that is, reserved dyed warp and weft) were made from silk and displayed many characteristics, mostly symmetrical motifs and patterns in predominantly red, black and white. They were produced by professional craftsmen (weavers) and traded by professional traders (Guy, 1998: 26, 87-88, 91-95). These textiles were produced originally for local contexts, but at a certain point in history when Gujarat became involved in transmaritime trade, these textiles were fed as commodities into networks of circulation that reached remote places in mainland and insular Southeast Asia, as far as the Bird's Head Peninsula in New Guinea (Barrkman, 2009; Miedema and Reesink, 2004).

4. Only a few villages specialised in distinct handicrafts, such as pottery, which draws on localised clay deposits.

5. The trade with patola continued (in an altered form) until the $20^{\text {th }}$ century, although the colonial powers had taken control of the intermaritime trade in Southeast Asia and also introduced European imitations textiles (Timmer, 2011: 388). I am grateful to Marie-Louise Nabholz-Kartaschoff, former curator of the Department of Asian Textiles Museum der Kulturen Basel, for her expert advice and discussing these complex issues with me. 
Apart from the extremely fine silk patola, workshops in Gujarat also produced special export cloth for which cotton was used and the same ornamentation was produced by block-printing and/or painting by hand (Guy, 1998; Barrkman, 2009: 160-161). These export textiles could be produced quickly and satisfied the apparently great demand of a wider public since they were less expensive. The trade in the cloth consisted of barter and sale, on the one hand, and of gifts in diplomatic relations, on the other hand (Barnes, 1989). Although patola had been goods circulated relatively freely during their transcultural journey, they were "diverted" from further circulation (Appadurai, 1986) as soon as they became the property of a noble family or clan. Most of these Indian textiles became heirlooms; they were, henceforth, inalienable; they served as marks of distinction and were used in ritual contexts (Barrkman, 2009).

The transcultural journey of the patola also produced a broad scope of translations and transpositions in a number of respects, such as names of motifs and patterns, as well as techniques, meanings and significance. ${ }^{6}$ The name patola for these highly valued textiles has been preserved, though with slight variations (see, for example, Nabholz-Kartaschoff, 1989) in only a few places in Indonesia. Other names were used in most of the sites where patola are kept. This applies even more to the names of motifs and patterns: they were adapted to local world-views (Barrkman, 2014). One of the typical patterns called chhabadi bhat, "eight-petalled lotus with four protruding buds and four blossoms" (and arranged in the form of an eight-pointed star) in Gujarat (Bühler and Fischer, 1979: 68), for example, is associated with flowers in several places. However, on a deeper, ritual level of interpretation, this design is interpreted consonant with the cosmological model: The protruding blossoms and buds, or flowers, are associated in Bali with the cardinal directions and their properties, such as particular deities and the corresponding colours and minerals (Nabholz-Kartaschoff, 1989: 190-197). However, in Flores, the same pattern, called ke'a, is explained in terms of the human body, with the liver being in the centre, the heart above, and below it, the breast, the hips and the back (de Jonge, 2016: 108).

The $i k a t$ technique, though not double-ikat ${ }^{7}$, was known in insular Southeast Asia (today's Indonesia) before the advent of the Indian patola (Barnes, 1989). The influx of patola, however, stimulated textile production with similar motifs and patterns in Indonesia in lots of ways (Barnes, 1989: 136). In many parts of Indonesia, such patterns were produced by applying the single-ikat technique (warp or weft ikat, see, for example, Barrkman, 2009, 2014; Nabholz-Kartaschoff, 1989, 1991) onto cotton threads. In central Kalimantan (as well as on Babar, Tanimbar and Madagascar), bast fibres were used instead (Barnes, 1989: 22). There were many more other transpositions as well, such as patola motifs and patterns produced by batik, block-printing and plangi techniques. In some cases, the textiles that were locally produced were assumed to be the original, whereas the Indian patola were considered as a variation of them (de Jonge, 2016). Nevertheless, most of the patola-inspired textiles produced locally were also integrated into the same or similar social and ritual contexts as the Indian imports: both were considered extremely powerful, apparently due to the same or similar motifs, patterns and colours.

In summing up the findings of the transcultural journeys of patola and the way they were received in insular Southeast Asia, we can establish that:

1) the distinction between "authentic" and export textiles was not crucial. Their mystical origin, the restricted supply, the motifs, colours and patterns constituted their major factors of attraction. These artefacts were, in most cases, diverted from further open circulation; they became heirlooms and were integrated into histories about the mythical time of the ancestors.

2) The names and interpretations of the motifs and patterns changed along the transcultural journeys and were adapted to local world-views. Accordingly, they became elements in culture-specific contexts - and even became constituents of them.

3) These cultural responses produced many cross-inspirations and led to local transpositions of techniques, materials, variations of patterns and their arrangement (though still following the basic principles of structure and colour). These local creations often reached the same status as the ones originally imported.

\section{Colonial collecting: "authentic" artefacts and their timeless life}

The large-scale collecting of artefacts in the Sepik and their trade started with the first explorers and gave rise to new forms of barter. As Roesicke stated in his diary in 1912, Sepik men brought all kinds of artefacts in their canoes to the German ship to barter for desirable goods (mainly iron tools) (Schindlbeck, 2015). Only the durable elements of the artefacts, so to say, "the skeletons",

6. Bühler and Fischer point out that the term patola, probably a Gujarat term to denote the double-ikat technique, was sometimes used in Indonesia as a generic term for Indian cloth in general (Bühler and Fischer, 1979, vol. 2: 291, ftn.7).

7. The only place in Indonesia where double-ikat textiles with overwhelming correspondences in motifs and patterns with patola are produced is Tenganan Pegeringsingan (Ramseyer, 1991). 
were collected; the manifold ephemeral attributes were disregarded. Moreover, the apparently almost insatiable demand of Europeans stimulated the local craftsmen and artists to produce artefacts for the purpose of bartering. Thus, a new form of production also started - the production of artefacts for export, in a similar way to the Gujarat textile producers who had started to produce rather inexpensive "export textiles". However, this comparison is flawed, since only newly made textiles entered the transmaritime trade in India. Conversely, the European explorers and traders favoured old artefacts, preferably made by stone tools and displaying traces of use. This peculiar taste may have been the result of the European's appreciation of "old cultures", first and foremost, those of classical antiquity - but expanding to other "early civilisations" in the wake of colonialism.

At the turn of the $19^{\text {th }}$ century, the dominant world-view in Europe was evolutionism. Accordingly, New Guinea (and other) cultures were seen to represent earlier stages of human cultural development. Thus, the emphasis in collecting was put on "authentic" artefacts that were understood as first-hand documents of archaic and primitive cultures. They embodied these qualities and were, at the same time, testimonies of indigenous ingenuity and world-view. In the decades following first contact, the collectors began to search for old pieces systematically. Thus, a kind of sale or selling off of old artefacts also started, the consequences of which local people were not always aware. ${ }^{8}$ The purposeful collection of old ritual artefacts implicated their disembedding (Giddens, 1991: 21-29). Consequently, the disembedding of artefacts implied a separation of time and space: The artefacts were lifted out of a long-lasting temporal-spatial continuity and were transported thousands of kilometres around the world to places where a completely new life started for them. As soon as the artefacts were dislocated from the places where they had been collected, their original context became blurred, since, in most cases, it was unclear whether these objects had been produced for local use or were newly made as export artefacts for sale to Europeans. Accordingly, this distinction became contingent or disputed in many cases.

These artefacts became re-embedded into locally (or nationally) predetermined contexts in the destination countries: into elite domains of socio-cultural life, such as museums, private collections, auction houses and art galleries. Similar to the patola traded to Indonesia, a substantial quantity of artefacts (but far from all) were diverted from further circulation: they were regarded mostly as inalienable cultural property of the destination country.9 This also implied a temporal change in the life of the artefacts: their ageing and deterioration was warded off by technical and chemical means. They were (and still are) supposed to, henceforth, lead a timeless or eternal life.

Most of the Indian textiles as commodities, regardless whether genuine ikat or made in a less expensive way, became precious goods in Indonesia and were used in rituals as attire, wrapping/cover or in ritualised exchange. Thus, the commodity was transformed into a sacred and inalienable treasure. In western collections, an inverse process took place: the transformation of ritual artefacts into a timeless material expression of objectified "culture". A special category of actors - artefact conserving and curating specialists - took control of them. These actors decided the way in which the artefacts were used - or rather displayed and interpreted. They also provided them with an evaluation of their "original" significance, use, age and meaning, exposing them to the gaze of (mostly paying) visitors. Thereby, artefacts became a means of instruction about other people's way of life and world-views - and their skills and aesthetics.

In Indonesia, the patola never became an object of scientific investigation and people apparently did not worry about their "original" use or the Gujarati classification, let alone their authentic cultural meaning. Nobody felt the need to follow the traces of the textile journeys to find out more about their "real" provenance. The nimbus of the unknown origin, the fine weaving, the ornamentation and their colours apparently constituted the value and attractiveness of the patola.

\section{New materialities and old stories}

In contrast to the seemingly unchanged Sepik artefacts acquired during the first half of the $20^{\text {th }}$ century (or even before) and preserved in western museums, profound social and religious changes have taken place in the Sepik: the impact of colonisation, the Second World War, proselytization, independence and, more recently, the threat to the Sepik environment by large-scale economic exploitation projects (mining and plantations). Apart from these challenges from the outside, the Sepik people themselves have made decisions to change their lives. Most of the Sepik people have become Christians and have also actively "modernised" their way of life in many respects, though

8. In former times, old, especially sacred, artefacts had been used as a source of inspiration to create a new one. The ancestors were consulted beforehand to achieve a "correct" replacement. The old one was either destroyed or left to deteriorate after the new artefact had been acknowledged by the ancestors (Hauser-Schäublin, 2017).

9. As Schindlbeck has shown, the circulation of museum objects started again when the argument of duplication of artefacts in collections was introduced (Schindlbeck, 2012). 
there are still striking continuities in the subsistence activities (Falck, 2016). Cellular phones are widespread, especially among young, urban, people and they consult all sorts of websites, including those of museums where Sepik collections are presented; they also engage in social networks. The Sepik people have become not only PNG nationals, but also world citizens. Moreover, Tok Pisin seems to be gradually replacing local languages in everyday communication (Jendraschek, 2012; Aikhenvald, 2008; Dobrin, 2014). Thus, language, too, is substantially changing and is even in danger of being lost.

Thus, the actual living world differs fundamentally from the world which Sepik artefacts in museum collections seem to represent. Consequently, they convey an image of timelessness, which is also reinforced by the way in which anthropologists and art historians talk and write about Sepik art. The evaluation of Sepik artefacts on the art market and the establishing of their prices still follow criteria of authenticity and antiquity. Such artefacts have become rare commodities over the past one hundred years; they are sold at exorbitant prices, as auctions show.

On the other hand, photographs of such old pieces have found their way back to the Sepik. They have stimulated Sepik artists and craftsmen to reproduce such artefacts by creating new "old" artefacts. However, it was not simply copying they have been carrying out; they rather adapted some of the newly made artefacts to the expectations and requirements (for example, concerning the portable size of objects) of tourists and art collectors. The main part of this production was made for sale, that is, for "export" (Silverman, 2008). As the example of the patola has shown, there are a number of processes of translation and transposition that have to be taken into account; this also applies to Sepik artefacts.

Similar to the patola, but even more far-reaching since PNG and the Sepik have been integrated in worldwide global networks, the agency of Sepik artefacts produced cross-inspirations on several levels, such as material, technique and form (size), as well as contexts, interpretation and meaning. This whole bundle of differing dimensions creates a kaleidoscopic composition of these elements that would need to be examined in more detail than I can do in this article. Nevertheless, even an artefact, such as a Sepik water drum, used in "traditional" contexts represents such a bundle of dimensions. The significance of each dimension varies according to the circle of people dealing with it, their knowledge and the relationship they have to this thing: the producers, the clan elders in charge of the ritual authority, the performers, the participants or initiates in a ritual, or those excluded from it (McDowell, 2015). The configuration of dimensions varies in each case, though there may be some shared understanding.
However, if the same object travels across cultural boundaries and meets other circles of people, such as tourists, art galleries, museums or private collectors, the configurations change substantially. Thus, one of the most striking features is that during a transcultural journey, a story told about the artefact - a complex of culture-specific understanding and values, imaginations, interpretations and goals - apparently becomes easily attached, detached and replaced by another story, again depending on the actors and their authority. Here, we notice a substantial difference to the pre-European patola trade. As far as we know, the textile that entered the transmaritime trade did so as an exquisite and expensive textile, however, only accompanied, if at all, by little stories. The stories about the long journey of the textiles and their origin faded the greater the distance between their origin and their final destination.

Since the earliest days of Sepik art acquisitions, stories about the artefact's origin, use and meaning were locally gathered or invented by foreigners; they became companions of the artefacts. Thousands of texts and other media about Sepik artefacts authored by non-Sepik people give evidence of this. Sepik artefacts were classified, dated and explained. As is well-known, there are always several versions of stories told about an artefact, but in a museum, it is the curator who decides which story s/he considers the most accurate. Sepik specialists have the authority and their stories are reproduced in books and rendered in a condensed form in labels "explaining" the exhibits. Consequently, as shown above, local people have sometimes started to relate what anthropologists published in books.

There have been many stories that have arisen from the materiality of artefacts or that were even uncoupled from them. However, the reverse may happen: the story remains the same, while the materiality of the artefact may change. As the case of the patola showed, the complicated technique of a double-ikat and even its simpler printed cotton export version had been transposed either into locally produced single-ikat technique or even batik techniques in Indonesia. These, too, possessed almost the same nimbus and power as the rare textiles from India for those who used them.

Many new tools and materials are easily accessible nowadays to create Sepik artefacts; these material innovations do not seem to change the artefacts' contents or stories. As is well-known, during a middle Sepik initiation, the primeval crocodile "bites" the male initiates - the young "crocodiles" - leaving scars on their skin (Wassmann, 1987). This dance is still performed (though apparently in different contexts). The crocodile dancer, who formerly wore a mask costume made of rattan and wood (like the one collected by the German explorers in 1912, see 


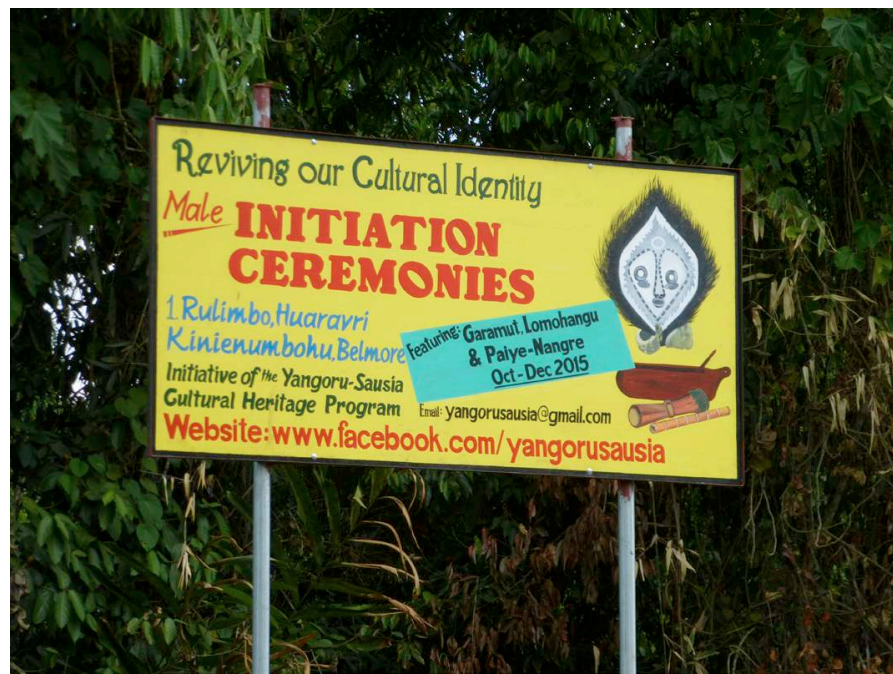

Рното 2. - Ritual practices and artefacts are used as manifestations of cultural identity, 2015 (C Brigitta Hauser-Schäublin)

photo 1), is nowadays clad in a synthetic crocodile costume with a big crocodile head. There is no information where the costume came from or who manufactured it, perhaps especially for this purpose. Nevertheless, it shows how the basic idea, the ritual embodiment of the primeval crocodile, has been transposed into new material and created a new realistic form of costume. It was the power of the story that mattered; it stimulated the search for new material and new forms.

\section{New stories and old designs}

During transcultural journeys, Sepik artefacts have given rise to new stories in different respects, new uses and new judgements about them. "Stories" are not restricted to verbalised explanations; they also comprise parts of the materiality of Sepik art. Motifs and forms are narrated visualisations which have their own attraction. As the patola example has already illustrated, motifs and patterns were apparently never copied by Indonesian weavers in the classical art historian sense (as an accurate replica). Instead, they were implemented and rearranged creatively by artists in new and culture-specific ways. Sepik motifs and forms have also served as inspirations. These narrated visualisations travel apparently as freely and easily as verbalized stories. They create new contexts and gather new audiences. It would be a project of research on its own to investigate the materials, techniques and contexts in which Sepik motifs and patterns have been transferred worldwide, by whom, and with what purpose and message. Transcultural journeys of Sepik art have also taken place within PNG. The public use and perception of Sepik artefacts and motifs and the messages ascribed to them in PNG differ from other, long distance, transcultural journeys, since they touch issues of national representation and identity. Among the best-known examples are decorative panels with Sepik motifs, understood as typical New Guinean artistic expressions, in many public buildings such as banks and airports, or the wooden holder for flags and door handles in the shape of Sepik drums at the National Parliament House in Port Moresby. These free-floating motifs and patterns generate, on the one hand, new artistic creations and reinterpretations consonant with the understanding ("seeing") and worldview of the onlooker. Consequently, new stories that originate from somewhere else become anchored in Sepik artistic expressions, too. The Vatican II Decree concerning the Roman Catholic Church's missionary activities states that

"the young churches [in the missionized countries may] borrow from the customs and traditions of their people, from their wisdom and their learning, from their arts and disciplines, all those things which can contribute to the glory of their Creator ..." (Decree ad gentes, chapter 3, no. 22)

Correspondingly, there are many examples of Roman Catholic Churches in PNG where Sepik art has been applied to the outside and interior of the buildings. Some churches and adjoining outbuildings have even taken on the form of Sepik men's houses, such as the meeting hall in Wirui (Wewak) in the shape of a Kwoma men's house. Many local buildings serving as churches are nowadays decorated with carvings, such as Sepik slit gongs or stools. In one case, an Abelam ngwalngwal motif (a face with huge eyes consisting of concentric circles) has been applied to the painted cross on the wall above the church's altar in Wewak's Teachers' College. This Sepik motif has replaced the holy cross, that is, the representation of Christ's body. A bird of paradise has been added to the ngwalngwals head decoration; it probably symbolises the Holy Spirit (photo 3). ${ }^{10}$

In these present-day religious contexts, artefacts also seem to move freely between Christian religious services and "traditional" rituals, as several examples show. At the consecration of a new bishop in Wewak in 2015 and his reception in Timbunke, the parish members were decorated with traditional ornaments - and even the bishop

10. We do not know whether the artist was a local artist or perhaps some outsiders, as was the case with the full-size painting in the tower of St. Mary's Cathedral in Port Moresby (created apparently by Dutch missionaries). 


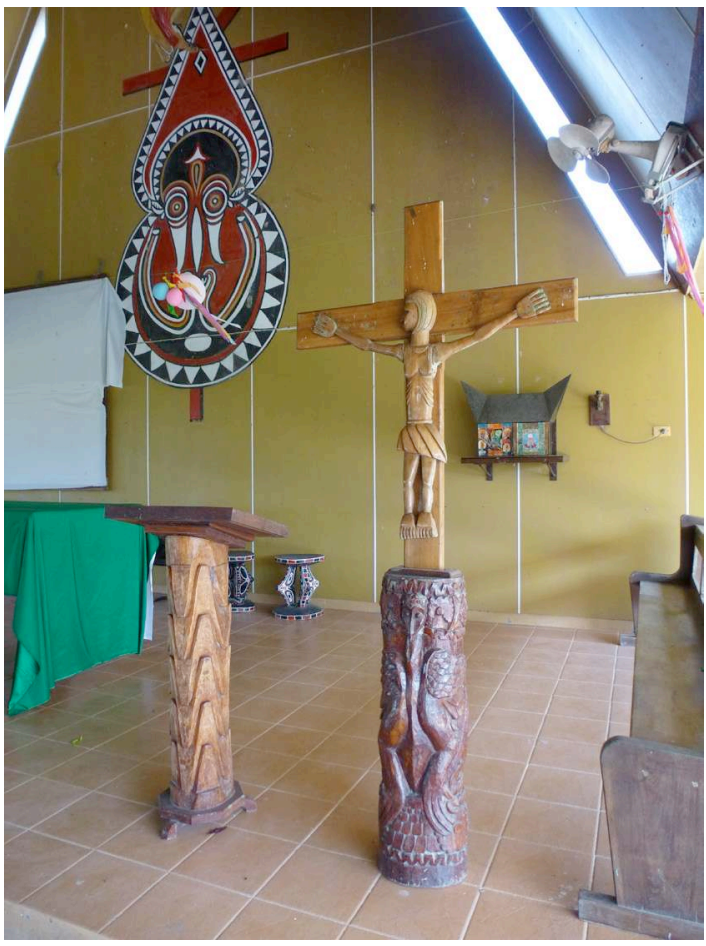

Рното 3. - Sepik carvings and paintings are used in new contexts and provided with new stories: Roman Catholic Church, Teachers' College, Wewak, 2015 (C) Brigitta Hauser-Schäublin)

officiating and carrying the crosier was adorned with New Guinean ritual ornaments. How far such Sepik artefacts tell a different story depending on the contexts or convey the same shared meaning, we do not know. These artefacts are most likely part of what is understood as cultural heritage and is used to express identity (photo 2).

However, Sepik art used in religious and even secular-public domains has not remained uncontested in PNG. Sepik images may create rival stories depending on the world-view of the onlookers. The followers of Christian denominations other than the Roman Catholic Church have a different attitude towards material expressions of unchristian beliefs and ritual practices, as the public dispute about the decoration of the National Parliament House in Port Moresby showed in 2013 (Geismar, 2014). Here, a new, moral, component was introduced when evaluating Sepik art and the message it carries. Art is not understood to convey messages about cultural achievements, a shared cultural identity, heritage or aesthetics. Instead, art became associated with paganism and an abhorrent lifestyle of the ancestors. For the followers of these Christian denominations, the Sepik art - understood as artistic "Sepikness" rather than products of individual "societies" - which decorated the most important public building of their nation embodied a lifestyle and ignorance of their forefathers of which they were ashamed. The critics of the use of traditional "art", led by

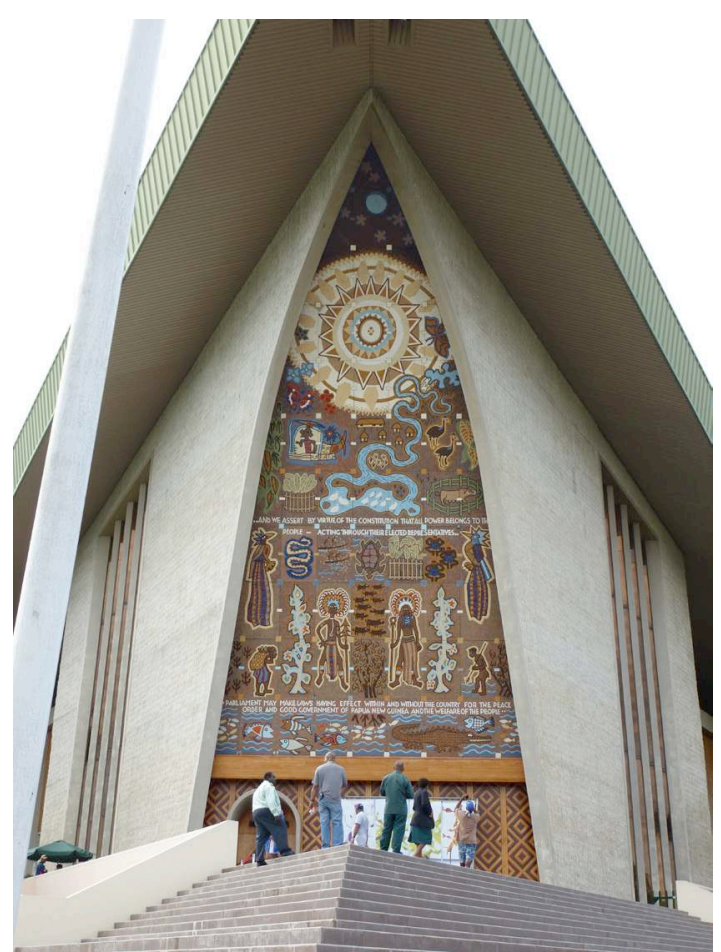

Рното 4. - The National Parliament House, Port Moresby, without the carved lintel, 2015 (C Brigitta Hauser-Schäublin)

the Speaker of Parliament, Theo Zurenuoc, and supported by Prime Minister O'Neill, referred to the fact that the Christian God and the faith in him is the foundation of PNG sociality and unity, as recorded in their nation's Constitution.

This building, inaugurated in 1984, had been designed by an Australian architect in collaboration with a team of students and artists from the PNG National Arts School (Rosi, 1991). This house was built after an Abelam ceremonial house. The main idea was that the National Parliament House is the national meeting house of PNG. One of the central messages of the house, the paintings and the carved lintels with 19 heads (symbolizing the 19 provinces) was to emphasise PNG's unity. In 2013, the decorations became an object of a fundamentalist attack and some decorative parts of the house were damaged. It was an iconoclasm that was taking place (photo 4). The huge carved pole (called a "totem pole") in the interior of the building was also to be removed. The Speaker of Parliament characterised this impressive carving displaying different PNG art styles and motifs as follows:

"The totem pole has three heads representing the god of witchcraft on the left, the god of immorality on the right and the god of idolatry in the middle." (The National, December 17, 2013)

It should, therefore, be replaced by a candle, several metres high, standing on a base resting on "The 


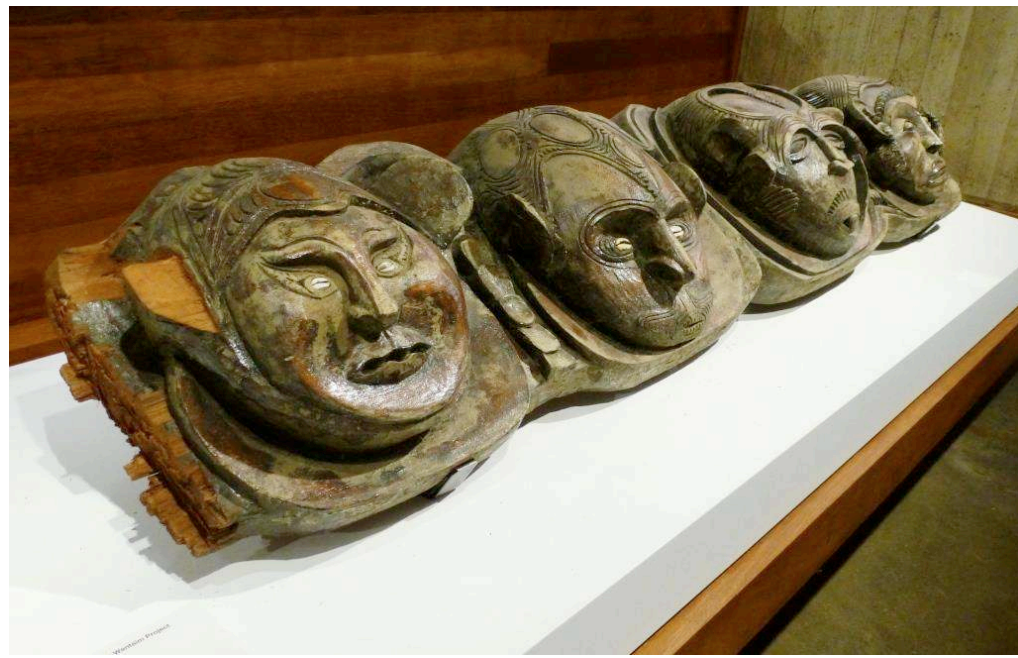

Рното 5. - Part of the wilfully broken lintel of the National Parliament House, now kept in the National Museum in Port Moresby, 2017 (C Brigitta Hauser-Schäublin)

Word of God" (Zurenuoc, n.d.). Hot debates took place. Many people, among them many artists, intellectuals and politicians, protested against this forceful and autocratic removal and the pejorative interpretation of the carved lintel and the "totem pole". They argued that this (and other PNG) art is cultural heritage that needs to be appreciated and protected (see Geismar, 2014; photo 5).

Thus, what had been conceived as a symbol of PNG culture by those who had created and authorised the construction of the National Parliament House was relegated to "religion" or assessed as a rather shameful belief of the ancestors. This reclassification, from culture to religion, was the reversed process from that which Sepik ritual objects underwent when Western explorers and collectors transferred them to museums. However, the moral declassification of the Sepik decorations at the National Parliament House did not remain uncontested. The case was brought before the National Court. In May 2016, the court ruled that the objects removed were protected under the National Cultural Property Act. It ordered that they be repaired and restored (Blades, 2016). However, Theo Zurenuoc filed an appeal challenging the National Court's ruling (The National, 2016). In short: the dispute about Sepik art being used as a decoration of the building of the National Parliament has not yet come to an end. It illustrates the clash of discourses and interpretations of Sepik art within the same nation. ${ }^{11}$

If we think, once again, back to the patola, we will realise that there we have no evidence of such conflicts arising over meanings due to a change in religious affiliation. One reason might be that $p a-$ tola always had mostly floral motifs and patterns and rarely images of the human body which might have created conflicts when Islam became the dominant religion. Moreover, patola were never used as symbols to express a national identity (which, anyway, never existed in the pre-colonial societies of the Southeast Asian archipelago). In addition, the elites using patola certainly chose the patterns according to their particular worldview of the time. Conversely, we would need to ask the question whether struggles over the decoration of the $\mathrm{Na}$ tional Parliament House in Port Moresby would have also arisen if only floral or other "abstract" patterns had been used.

\section{Conclusion}

This article has dealt with different types of interand transcultural journeys: those (intercultural) that took place in the Sepik basin in pre-colonial times and those (transcultural) which started only with the penetration of European explorers. The pre-colonial exchange and journeys of people, ideas and artefacts resulted in the development of similarities, "Sepikness", which also displays efforts of distinction. This "Sepikness" as an ongoing shifting of relationships, people and artefacts within the region had been a continuous process. It came to a halt when colonisation started. With it, new relationships were established that outreached the Sepik by far. They resulted in transcultural journeys when colonial explorers and travellers started the large-scale collecting of artefacts and transported them overseas. Against the backdrop of the transmaritime trade of patola textiles from India to sites in insular Southeast Asia (today's Indonesia) and their localisation there, distinct features of Sepik collecting by outsiders were uncovered: western collectors preferred old and "authentic", especially ritual artefacts. Thus, they were in search of artefacts that had been used. This implied a disembedding of the Sepik artefacts from their cultural contexts which sometimes left "gaps" behind. On their transcultural journeys, the artefacts were provided with new lives and became re-embedded in secular and elite contexts - in public museums and private collections - in the destination countries. In

11. There are some rumours which relate these destructive actions to rivalries between representatives of different provinces. However, as the celebration of the annual Repentance Day (introduced in 2011) shows, the concern about moral issues is predominant. 
contrast to the trade of patola, Sepik artefacts were continuously supplied with new stories about their cultures of origin and their "meaning". These were stories, developed on the basis of the collectors and explorers' worldview and the dominant theories of the time. Consequently, they included interpretations of aesthetics, style and "primitive" cultures. These authoritative narratives were conceived as both educational and scientific and were drafted for a western audience. Thus, the artefacts' significance was rooted in these stories; they became almost as important as the artefacts themselves.

Conversely, Sepik collections and pictures of them also stimulated art production in the Sepik and PNG many decades after the first artefacts had been gathered. Many of these recent forms of art production are made by following the model of "old" and "authentic" artefacts, at least those made for sale. However, new materials also entered the Sepik, replacing old ones. Nevertheless, artefacts made for local use and manufactured from new materials were provided with "old" stories.

With the worldwide dissemination of pictures of Sepik art, Sepik motifs and patterns started to float freely (not least through the media) and are being used at will as decorative elements. Thus, the materiality, concepts and beliefs associated with them and the corresponding stories about Sepik artefacts have become entities detached from each other. However, particular groups of onlookers associate definite ideas and stories with Sepik material artistic expressions - and vice ver$s a$. Additionally, even Sepik motifs and patterns may indicate or even embody different things to the same onlookers, depending on the context in which these artefacts, motifs or patterns are experienced. Thus, the relationship between materiality and immateriality is not random, and this is illustrated in PNG by the followers of different Christian denominations, for whom Sepik artefacts represent completely different values and beliefs. The Sepik-style decorations in the National Parliament House in Port Moresby has evoked conflicting stories and led to disputes over moral issues of the meanings and purpose these artefacts represented at symbolically the most important public building of the nation.

\section{REFERENCES}

Aikhenvald Alexandra Y., 2008. The Manambu language of East Sepik, Papua New Guinea, Oxford, Oxford University Press (http://researchonline.jcu.edu.au/9635/3/9635_Aikenvald_2008_ front_pages.pdf < November 14, 2016>).

Appadurai Arjun, 1986. Introduction: commodities and the politics of value, in A. Appadurai (ed.), The social life of things: commodities in cultural perspective, Cambridge, Cambridge University Press, pp. 3-63.
—, 1996. Globalization at large: cultural dimensions of globalization, Minneapolis, University of Minnesota Press.

BARnes Ruth, 1989. The ikat textiles of Lamalera. A study of an Eastern Indonesian weaving tradition, Leiden, E.J. Brill.

BARRKMAN Joanna, 2009. Indian patola and trade cloth influence on the textiles of the Atoin Meto people of west Timor, Archipel 77, pp. 155-182.

—, 2014. 'She comes with a spindle in her hand'. Biboki textiles, in R. W. Hamilton and J. Barrkman (eds), Textiles of Timor, island in the woven sea, Los Angeles, Fowler Museum at UCLA, pp. 123-135.

Blades Johnny, 2016 (May 6). Cultural carvings on png National Parliament restored after court ruling, Pacific Island Report (http://www.pireport.org/articles/2016/06/05/cultural-carvings-png-national-parliament-restored-after-court-ruling, <November 21, 2016>).

BüHLER Alfred, 1960. Kunststile am Sepik, Basel, Museum für Völkerkunde.

BüHLER Alfred and Eberhard Fischer, 1979. The Patola of Gujarat. Double ikat in India, Basel, Krebs.

ClaAs Ulrike, 2007. Das Land entlang des Sepik: Vergangenheitsdarstellungen und Migrationsgeschichte im Gebiet des mittleren Sepik, Papua New Guinea, Berlin, Lit., Göttinger Studien zur Ethnologie 17.

—, 2009. "Fish, water, and mosquitoes": The Western invention of Iatmul culture, in E. Hermann, K. Klenke und M. Dickhardt (Hg.), Form, Macht, Differenz. Motive und Felder ethnologischen Forschens, Göttingen, Universitätsverlag, pp. 215-226.

Decree ad gentes on the mission activity of the church. Documents of Concile Vatican II (http:// www.vatican.va/archive/hist_councils/ii_vatican_ council/documents/vat-ii_decree_19651207_ ad-gentes_en.html, <03/24/2017>).

Dobrin Lise M., 2014. Language shift in an 'importing culture': The cultural logic of the Arapesh roads, Proceedings of The British Academy 199, pp. 125-148 (https://anthropology. virginia.edu/sites/anthropology.virginia.edu/ files/Dobrin-2014-Language.Shift.in.an.Importing.Culture.pdf, <09/08/2016>).

FALCK Christiane, 2016. Calling the dead. Spirits, mobile phones, and the talk of god in a Sepik community, Ph.D. thesis, James Cook University and Aarhus University, Manuscript.

Foley William A., 2017. The languages of the Sepik-Ramu Basin and environs, in B. Palmer (ed.), The languages and linguistics of the New 
Guinea area. A comprehensive guide, Berlin, Walter des Gruyter, pp. 197-431.

Forge Anthony, 2017. Draft introduction to Sepik Culturel History, the proceedings from the second Wenner-Gren conference on Sepik Culture History 1986, Mijas, Spain, in A. Clark and N. Thomas (eds), Style and Meaning. Essays on the anthropology of art. Anthony Forge, Leiden, Sidestone Press, pp. 153-178.

GeIsmar Haidy, 2014. A new government breaks with the past in the Papua New Guinea Parliament's "Haus Tambaran", Material World (http://www.materialworldblog. com/2014/02/a-new-government-breakswith-the-past-in-the-papua-new-guinea-parliaments-haus-tambaran/, <25/06/2015>).

Gell Alfred, 1998. Art and agency. An anthropological theory, Oxford, Oxford University Press.

Gewertz Deborah, 1983. Sepik river societies: $A$ historical ethnography of the Chambri and their neighbours, New Haven, Yale University Press.

Giddens Anthony, 1991. Consequences of modernity, Cambridge, Polity.

Guy John, 1998. Woven cargoes. Indian textiles in the East, London, Thames and Hudson.

Hauser-SchäUblin Brigitta, 2016. The ceremonial house of the Abelam - a passage to the ancestors, Goolwa, Crawford House Publishing.

—, 2017. The Dancers who became transformed into wood: the mai masks of the Iatmul, Papua New Guinea, Oceania 87 (3), pp. 234-260.

JENDRASCHEK Gerd, 2012. A grammar of Iatmul, Habilitationsschrift, Universität Regensburg, Fakultät für Sprach-, Literatur- und Kulturwissenschaften.

Jonge De Willemijn, 2016. Das Schultertuch luka semba: Trans-Lokalität in Flores, in Mustergültig. Globale Spuren in der lokalen Ikat-Mode, Museum der Kulturen Basel, pp. 104-114.

Kocher Schmid Christin, 2015. Waffenbrüder und Ahnengeister. Das Ritualsystem der Zentral-Iatmul, in P. Peltier, M. Schindlbeck and C. Kaufmann (eds), Tanz der Ahnen. Kunst vom Sepik in Papua-Neuguinea, München, Hirmer, pp. 62-69.

Lutkehaus Nancy and Paul Roscoe, 1987. Sepik culture history: Variation, innovation, and synthesis, Current Anthropology 28 (4), pp. 577-581.

McDowell Nancy, 2015. Flöten. Austausch und Bedeutung im Yuat-Gebiet, in P. Peltier, M. Schindlbeck and C. Kaufmann (eds), Tanz der Ahnen. Kunst vom Sepik in Papua-Neuguinea, München, Hirmer, pp. 46-53.
Mead Margaret, 1938. The Mountain Arapesh. 1. An importing culture, Anthropological Papers of the American Museum of Natural History 36 (3), pp. 145-349.

Miedema Jelle and Ger Reesink, 2004. One head, many faces; new perspectives on the Bird's Head Peninsula of New Guinea, Leiden, KItLv Press.

Mijas CONFerence, 1986. Abstract of "Sepik culture history: variation and synthesis" (http://www.wennergren.org/history/conferences-seminars-symposia/wenner-gren-symposia/cumulative-list-wenner-gren-symposia/w-109, <November 7, 2016>).

Nabholz-Kartaschoff Marie-Louise, 1989. A sacred cloth of Rangda. Kamben cepuk of Bali and Nusa Penida, in M. Gittinger (ed.), To speak with cloth. Studies in Indonesian Textiles, Los Angeles, Museum of Cultural History, University of California, pp. 181-197.

-, 1991. Cepuk. Sacred textiles from Bali and Nusa Penida, in B. Hauser-Schäublin, M.L. Nabholz-Kartaschoff and U. Ramseyer (eds), Textiles in Bali, Berkeley, Singapore, Periplus, pp. 95-114.

Newton Douglas, 2015. Ahnenbegegnungen, in $\mathrm{P}$. Peltier, M. Schindlbeck and C. Kaufmann (eds), Tanz der Ahnen. Kunst vom Sepik in Papua-Neuguinea, München, Hirmer, pp. 14-21.

Peltier Philippe and Markus Schindlbeck, 2015. Einleitung, in P. Peltier, M. Schindlbeck and C. Kaufmann (eds), Tanz der Ahnen. Kunst vom Sepik in Papua-Neuguinea, München, Hirmer, pp. 78-105.

Ramseyer Urs, 1991. Geringsing. Magical protection and communal identity, in B. Hauser-Schäublin, M.L. Nabholz-Kartaschoff and U. Ramseyer (eds), Textiles in Bali, Berkeley, Singapore, Periplus, pp. 117-135.

Reche Otto, 2015 [1913]. The Empress Augusta / Sepik River, Otago, University of Otago, University of Otago Working Papers in Anthropology 2.

Roscoe Paul B., 1989. The flight from the fen: the prehistoric migrations of the Boiken of the East Sepik Province, Papua New Guinea, Oceania 60 (2), pp. 139-154.

Rosi Pamela C., 1991. Papua New Guinea's New Parliament House: A contested national symbol, The Contemporary Pacific 3 (2), pp. 289-323.

SCHINDLBECK Markus, 2012. Gefunden und verloren: Arthur Speyer, die dreißiger Jahre und die Verluste der Sammlung Südsee des Ethnologischen Museums Berlin, Bönen, Kettler.

—, 2015. Unterwegs in der Südsee. Adolf Roesicke und seine Fahrten auf dem Sepik in Neuguinea, Berlin, Ethnologisches Museum. 
—, 2017. Von Kathedralen und Elefantenherden: Die Berliner Abelam-Sammlung, Baessler-Archiv 64, pp. 19-38.

SiLverman Eric Kline, 1993. Tambunum, 2 volumes, Ph.D. Dissertation, University of Minnesota, Ann Arbor, University Microfilms International.

—, 2008. Moderate Expectations and benign exploitation: Tourism on the Sepik River, Papua New Guinea, in J. Connell and B. Rugendyke (eds), Tourism at the grassroots. Villagers and visitors in the Asia-Pacific, London, Routledge, pp. 58-76.

Speiser Felix, 1937. Kunststile in Melanesien, Z.f.E. 68, pp. 304-369.

Swadling Pamela, 1996. Plumes of paradise: trade cycles in Outer Southeast Asia and their impact on New Guinea and nearby islands until 1920, Port Moresby, Papua New Guinea National Museum.

The NATional, 2013 (December 17). Zurenuoc: I am not a cultural terrorist (http://www.thenational.com.pg/zurenuoc-i-am-not-a-cultural-terrorist/, < November 30, 2016>).
—, 2016 (July 12). Court's decision disputed (http://www.thenational.com.pg/courts-decision-disputed/, <November 30, 2016>)

Timmer Jaap, 2011. Cloths of civilization: kain timur in the Bird's Head of West Papua, The Asia Pacific Journal of Anthropology 12 (4), pp. 383-401.

Wassmann Jürg, 1987. Der Biss des Krokodils: Die ordnungsstiftende Funktion der Namen in der Beziehung zwischen Mensch und Umwelt am Beispiel der Initiation, Nyaura, Mittel-Sepik, in M. Münzel (ed.), Neuguinea, Nutzung und Deutung der Umwelt, Bd. 2, Roter Faden zur Ausstellung 13, Frankfurt, Museum für Völkerkunde, pp. 511-557.

-, 1991. The song to the flying fox. The public and esoteric knowledge of the important men of Kandingei about totemic songs, names, and knotted cords (Middle Sepik, Papua New Guinea), Port Moresby, Institute of Papua New Guinea Studies.

ZuRENuOC Theo, n.d. Restoration, reformation and modernisation of the National Parliament, Port Moresby, Office of the Speaker. 